\title{
DIRHAMNOSYL FLAVONOID AND OTHER CONSTITUENTS FROM Brillantaisia palisatii
}

Luciane Fátima Berrondo, Felipe Teixeira Gabriel, Sidnei Bessa de Oliveira Fernandes and Fábio de Sousa Menezes*

Departamento de Produtos Naturais e Alimentos, Faculdade de Farmácia, Universidade Federal do Rio de Janeiro, Centro de Ciências da Saúde, Bloco A, Ilha da Cidade Universitária, 21941-590 Rio de Janeiro - RJ

Davyson de Lima Moreira

Faculdade de Farmácia, Universidade de Barra Mansa, Rua Vereador Pinho de Carvalho 267, 27330-550 Barra Mansa - RJ

Recebido em 17/7/02; aceito em 10/4/03

\begin{abstract}
DIRHAMNOSYL FLAVONOID AND OTHER CONSTITUENTS FROM Brillantaisia palisatii. A mixture containing sitosterol and stigmasterol; a new triterpene 3-epi-ursolic acid; another triterpene mixture comprising $\alpha$-amyrin, $\beta$-amyrin and lupeol; verbascoside, a phenylpropanoid glycoside; and lespedin, a glycosyl flavonoid, were isolated. The less polar compounds (steroids and triterpenoids) were isolated from the hexane partition of the crude ethanolic extract while the more polar ones (phenylpropanoid glycoside and glycosyl flavonoid) were isolated from the ethyl acetate partition of the same extract. The structures of all compounds were established using modern spectrometric methods of elucidation. The spectroscopic data of Lespedin, a rare dirhamnosylflavonol with hypotensor activity and of the triterpene, 3-epi-ursolic acid, are also reported.
\end{abstract}

Keywords: Brillantaisia palisatii; dirhamnosyl flavonol; triterpenes.

\section{INTRODUCTION}

Brillantaisia palisatii Lind. belongs to the family Acanthaceae, order Scrophulariales, superorder Lamiifrorae ${ }^{1}$. Into this family $B$. palisatii is classified in the subfamily Acanthoideae, tribus Hygrophyllae $^{2}$. Acanthaceae is composed of about 250 genera with almost 2500 species spread over tropical regions, at the Mediterranean, United States of America and Australia ${ }^{3}$. The main four distribution centers of this family are Indomalay (Strobilanthes and Andrographis), Africa (Barleria), Brazil (Ruellia) and Central America (Aphellandra and Odontonema). These plants show a wide variety in habit and biological types. Most of them are shrubs or herbs, climbing plants, xerophytes and marshy plants are also very common. Trees, however, are rare in the family ${ }^{4}$. The chemistry of Acanthaceae shows a great diversity of different compounds such as alkaloids ${ }^{5}$, iridoids ${ }^{6}$, lignans ${ }^{7}$, flavonoids ${ }^{8}$, terpenoids ${ }^{9}$ and phenylpropanoid glycosides ${ }^{10}$. Some species of this family are used in folk medicine to treat several diseases, especially gastrointestinal ailments. In fact, several compounds isolated from species belonging to the family Acanthaceae have comproved pharmacological activities.

\section{METHODOLOGY}

Aerial parts of Brillantaisia palisatii Lind. were collected near the Rio de Janeiro Botanical Garden, Rio de Janeiro State, Brazil, in April, 1997. Several herbarium samples (Voucher numbers $=289308$, $251777,173808,267291$, etc.) have been deposited at the Rio de Janeiro Botanical Garden herbarium. There are no reports about the traditional uses of this species as well as about its chemical composition.

Vegetative organs were extracted with ethanol and after that, extraction procedures using liquid-liquid partition were made in order to produce extracts with hexane, dichloromethane, ethyl acetate and

*e-mail: fsmenezes@pharma.ufrj.br $n$-butanol. The purification step using chromatographic methods lead to several known molecules, including the rare favonol lespedin and also to a new one, a triterpene named 3-epi-ursolic acid.

\section{RESULTS}

The hexanic partition of the $B$. palisatii crude ethanolic extract was chromatographed on a silica gel column to give two main fraction apparently pure on TLC. These fractions were analyzed by GC revealing that they were actually mixtures. The less polar mixture, eluted with hexane-EtOAc (95:5) consisted of three compounds $(0.0229 \%)$. GC-MS analysis of this mixture showed that all of the three compounds have a mass spectra with $[\mathrm{M}]+=\mathrm{m} / \mathrm{z}, 426$ in agreement with the following formula $\mathrm{C}_{30} \mathrm{H}_{50} \mathrm{O}$. The characterization of the constituents of the less polar triterpene mixture as well as of the more polar constituents was simplified by the assignment of the carbon atoms in the ${ }^{13} \mathrm{C}$ NMR. As the chemical shift of a sp ${ }^{2}$ carbon atom is very characteristic for each triterpenoid skeleton, ${ }^{13} \mathrm{C} \mathrm{NMR}$ spectroscopy has been very frequently employed for the structural analysis of triterpene mixtures ${ }^{11}$. To distinguish carbon types (multiplicity), the attached proton test (APT) was used. Thus, it appeared in the ${ }^{13} \mathrm{C}$ NMR spectrum signals at $\delta 78.8 \mathrm{ppm}$ relative to $\mathrm{C}_{3}$ of the three constituents; $\delta 150.7$ and $109.2 \mathrm{ppm}$ corresponding to olefinic carbons $\mathrm{C}_{20}-\mathrm{C}_{29}$ of the lupane skeleton; $\delta 121.6$ and 145.0 ppm corresponding to olefinic carbons $\mathrm{C}_{12}-\mathrm{C}_{13}$ of the oleanane skeleton and $\delta 124.3$ and 139.4 ppm corresponding to olefinic carbons $\mathrm{C}_{12}-\mathrm{C}_{13}$ of the ursane skeleton. These data, together with those obtained by GC-MS and ${ }^{1} \mathrm{H}$ NMR, confirmed the presence of lupeol, $\alpha$-amyrin and $\beta$-amyrin in this triterpene mixture in the following estimated proportions: $2: 1: 1$, respectively.

The more polar mixture $(0.00487 \%)$, eluted with hexane-EtOAc (9:1), presented characteristic signals of olefinic carbons for sitosterol and stigmasterol ${ }^{12}$ in an estimated proportion of $1: 1$. Another compound $(0.00299 \%)$, isolated with hexane-EtOAc (8:2), showed the ${ }^{13} \mathrm{C}$ NMR spectrum with a group of signals at $\delta 178.02\left(\mathrm{C}_{28}\right)$, $140.50\left(\mathrm{C}_{13}\right), 121,48\left(\mathrm{C}_{12}\right)$ and 74,53 $\left(\mathrm{C}_{3}\right)$, consistent with the signals of the 3-epi-ursolic acid (1) ${ }^{11}$, which was supported by ${ }^{1} \mathrm{H}$ NMR data 
showing a multiplet centered at $\delta 3.5 \mathrm{ppm}\left(\mathrm{H}_{3}\right)$. The confirmation of this proposal was made by GC-MS analysis of the methylated molecule, which showed just one signal $\left(R_{t}=76.02 \mathrm{~min}\right.$. $)$ corresponding to 3-methyl-epi-ursolate, with mass spectra having $[\mathrm{M}]+=m / z, 470$.

The ethyl acetate partition of $B$. palisatii crude ethanolic extract was chromatographed on a silica gel column to give a mixture of two compounds apparently pure on TLC. This mixture was eluted from the column with $\mathrm{CHCl}_{3}: \mathrm{MeOH}$ (7:3). After ${ }^{1} \mathrm{H} \mathrm{NMR}$ analysis it was clear that this compound actually was a mixture of two substances: verbascoside (the major constituent, 0,00868\%) and lespedin (the minor constituent, 0,00967\%). The separation was performed by Sephadex LH-20 chromatography. Analysis by ${ }^{1} \mathrm{H}$ NMR and ${ }^{13} \mathrm{C}$ NMR could identify these two compounds unequivocally, when compared with literature data ${ }^{13,14}$.

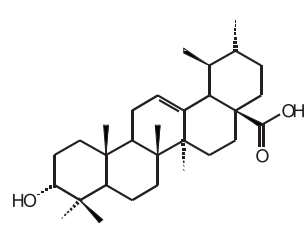

3-epi-ursolic acid (1)

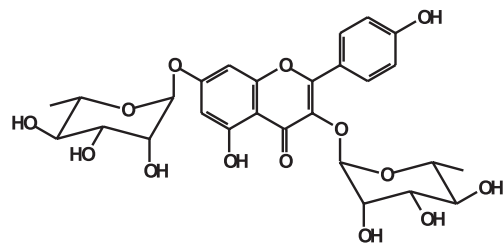

lespedin (2) 3-epi-ursolic acid (1)

It was obtained as colorless amorphous powder $\left(\mathrm{CHCl}_{3}\right)$ : mp 250-252 ${ }^{\circ} \mathrm{C}$; ${ }^{1} \mathrm{H}$ NMR (200 MHz, $\left.\mathrm{CDCl}_{3}, \mathrm{TMS}\right): \delta$ (ppm): 0.73-1.11 (H methyl signals), $3.5\left(m, \mathrm{H}_{3}\right), 5.1\left(t, J 3.2 \mathrm{~Hz}, \mathrm{H}_{12}\right) ;{ }^{13} \mathrm{C}$ NMR $(50$ $\left.\mathrm{MHz}, \mathrm{CDCl}_{3}, \mathrm{TMS}\right): \delta(\mathrm{ppm}): 15.5\left(\mathrm{C}_{24}\right), 15.7\left(\mathrm{C}_{25}\right), 16.5\left(\mathrm{C}_{29}\right), 16.6$ $\left(\mathrm{C}_{26}\right), 18.4\left(\mathrm{C}_{6}\right), 21.4\left(\mathrm{C}_{30}\right), 23.3\left(\mathrm{C}_{11}\right), 23.6\left(\mathrm{C}_{27}\right), 24.2\left(\mathrm{C}_{16}\right), 27.4$ $\left(\mathrm{C}_{2}\right), 27.9\left(\mathrm{C}_{15}\right), 28.4\left(\mathrm{C}_{23}\right), 30.7\left(\mathrm{C}_{21}\right), 32.9\left(\mathrm{C}_{7}\right), 36.7\left(\mathrm{C}_{22}\right), 37.0$ $\left(\mathrm{C}_{10}\right), 38.8\left(\mathrm{C}_{1}, \mathrm{C}_{4}, \mathrm{C}_{20}\right), 39.1\left(\mathrm{C}_{17}\right), 39.5\left(\mathrm{C}_{8}\right), 42.0\left(\mathrm{C}_{14}\right), 47.2\left(\mathrm{C}_{17}\right)$, $47.4\left(\mathrm{C}_{9}\right), 52.8\left(\mathrm{C}_{18}\right), 55.3\left(\mathrm{C}_{5}\right), 74.5\left(\mathrm{C}_{3}\right), 121.5\left(\mathrm{C}_{12}\right), 140.5\left(\mathrm{C}_{13}\right)$, $178.0\left(\mathrm{C}_{28}\right)$

GC (DB-1, Temp. Prog. $60^{\circ}-240^{\circ} / 3^{\circ} \mathrm{min}$. ) - $76.02 \mathrm{~min}$.

EIMS $m / z$ (rel. int.): $470[\mathrm{M}]^{+.}$(3), 411 (2), 262 (100), 249 (6), 233 (7), 207 (33), 203 (84), 189 (22), 133 (81), 119 (33), 95 (28), 69 (41), 55 (59), 43 (79).

Lespedin (2)

It was obtained as an yellow needles $(\mathrm{MeOH}): \mathrm{mp} 219-221{ }^{\circ} \mathrm{C}$; U.V. $\lambda_{\text {máx }}(\log \varepsilon) \mathrm{MeOH}: 341.4$ (0.958), 265.6 (1.807), 204.6
(1.985).U.V. $\lambda_{\text {má }}(\log \varepsilon) \mathrm{MeOH}+\mathrm{AlCl}_{3}: 348.6(0.850), 273.6$ (1.355), 207.6 (2.036).U.V. $\lambda_{\text {máx }}(\log \varepsilon) \mathrm{MeOH}+\mathrm{AlCl}_{3}+\mathrm{HCl}: 341.0$ (0.803), 275.0 (1.565), 206.6 (1.861). U.V. $\lambda_{\text {máx }}(\log \varepsilon) \mathrm{MeOH}+\mathrm{AcONa}$ : 343.4 (0.493), 265.4 (0.680), 203.0 (1.746); ${ }^{1} \mathrm{H}$ NMR (200 MHz, MeOD, TMS): $\delta$ (ppm): 0.95 (d, $\left.J 5.6 \mathrm{~Hz}, \mathrm{H}_{6} \mathrm{Rha} 3\right), 1.28$ (d, $J 5.9$ $\mathrm{Hz}, \mathrm{H}_{6} \mathrm{Rha7}$ ) 3.30-4.30 (signals relative to protons 2-5 belonging to the two rhamnose residues), $5.40\left(d, J 1.6 \mathrm{~Hz}, \mathrm{H}_{1} \mathrm{Rha3}\right), 5.57(d, J$ 1.6 Hz, H Rha7), $6.44\left(d, J 2.1 \mathrm{~Hz}, \mathrm{H}_{8}\right), 6.70\left(d, J 2.1 \mathrm{~Hz}, \mathrm{H}_{6}\right), 6.94$ $\left(d, J 8.8 \mathrm{~Hz}, 2 \mathrm{H}, \mathrm{H}_{3}, 5,\right), 7.78\left(d, J 8.8 \mathrm{~Hz}, 2 \mathrm{H}, \mathrm{H}_{2},{ }_{6}\right) ;{ }^{13} \mathrm{C} \mathrm{NMR}(50$ MHz, MeOD, TMS): $\delta$ (ppm): 17.7 ( $\mathrm{C}_{6}$ Rha7), 18.1 ( $\mathrm{C}_{6}$ Rha3), 71.2 ( $\mathrm{C}_{5}$ Rha7), 71.6 ( $\mathrm{C}_{5}$ Rha3), 71.8 ( $\mathrm{C}_{2}$ Rha3), 72.1 ( $\mathrm{C}_{2,3}$ Rha7 and $\mathrm{C}_{3}$ Rha3), 73.1 ( $\mathrm{C}_{4}$ Rha7), 73.5 ( $\mathrm{C}_{4}$ Rha3), $95.5\left(\mathrm{C}_{8}\right), 99.8\left(\mathrm{C}_{6}\right), 100.5$ (C $\mathrm{C}_{1}$ Rha7), $103.5\left(\mathrm{C}_{1} \mathrm{Rha3}\right), 107.5\left(\mathrm{C}_{8 \mathrm{~b}}\right), 116.6\left(\mathrm{C}_{3,5}\right), 122.3\left(\mathrm{C}_{1}\right)$, $131.9\left(\mathrm{C}_{2,6},{ }\right), 136.4\left(\mathrm{C}_{3}\right), 157.9\left(\mathrm{C}_{8 \mathrm{a}}\right), 159.7\left(\mathrm{C}_{2}\right), 161.7\left(\mathrm{C}_{4}\right), 162.9$ $\left(\mathrm{C}_{5}\right), 163.5\left(\mathrm{C}_{7}\right), 179.7\left(\mathrm{C}_{4}\right)$.

\section{ACKNOWLEDGEMENTS}

Authors are indebted to FUJB, FAPERJ and PRONEX for financial support.

\section{REFERENCES}

1. Dahlgren, R. M. T.; Botanical Journal of the Linnean Society 1980, 80, 91

2. Engler, A.; Syllabus der Pflanzenfamilien, Gerbruder Borntraeger: Berlin, 1964.

3. Brummet, R. K.; Vascular Plants, Families and Genera, Royal Botanical Gardens: Kew, 1992

4. Joly, A. B.; Introdução à Taxonomia Vegetal, Ed. Nacional: São Paulo, 1985.

5. Werner, C.; Hedberg, C.; Lorenzi-Riatsch, A. L.; Hesse, M.; Phytochemistry 1993, 33,1033.

6. Boros, C. A.; Stermitz, F. R.; J. Nat. Prod. 1991, 54, 1173.

7. Jyotishi, S. G.; Bagavant, G.; Ind. J. Nat. Prod. 1992, 8, 3.

8. Bratoeff, E. A.; Perez-Amador, M. C.; Phyton International Journal of Experimental Botany 1994, 56, 27.

9. Mukherjee, K. S.; Laha, S.; Chakraborty, C. K.; J. Indian Chem. Soc. 1991, $68,634$.

10. Henry, M.; Roussel, J. L.; Andary, C.; Biotechnology Agricultural Forest 1993, 21, 207.

11. Mahato, S. B.; Nandy, A. K.; Roy, G.; Phytochemistry 1992; 31, 2199.

12. Wright, J. L. C.; McInnes, A. G.; Shimizu, S.; Smith, D. G.; Walter, J. A.; Can. J. Chem. 1978, 56, 1898.

13. Andary, C.; Wylde, R.; Laffite, C.; Privat, G.; Winternitz, F.; Phytochemistry 1982, 21, 1123.

14. Gohar, A. A.; Elmazar, M. M. A.; Phytotherapy Research 1997, 11, 564. 